\title{
Accounting and stereotypes. A comparative analysis of Mexican students' perceptions
}

\author{
Contabilidad y estereotipos: Un análisis comparativo de las \\ percepciones de estudiantes Mexicanos
}

\author{
Carmen Fernández-Polvillo (carmenfp@us.es) \\ Orcid: 0000-0002-6979-6946 \\ Departamento de Economía Financiera y Dirección de Operaciones \\ Universidad de Sevilla (España)
}

\author{
Gracia Patricia Michel Vázquez (graciapa@cucsur.udg.mx) \\ Orcid: 0000-0002-1831-7001 \\ Universidad de Guadalajara / CUCSUR (México)
}

http://dx.doi.org/10.12795/EDUCADE.2018.109.03

\begin{abstract}
RESUMEN: Tanto los posicionamientos de instituciones contables como los resultados de la investigación recogen la existencia del llamado gap de expectativas, una divergencia entre los requisitos en capacidades para tener éxito en la profesión contable y las capacidades que tienen los recién graduados. Algunos autores apuntan a una interpretación errónea de los requisitos profesionales por parte de los estudiantes, basada en una visión estereotipada de la contabilidad, lo que puede llevar a un sesgo de autoselección. El principal objetivo de este trabajo es analizar las percepciones sobre la contabilidad de una muestra de estudiantes mexicanos matriculados en distintas carreras y cursos. Nuestros resultados, al contrario de los obtenidos por otros trabajos sugieren que los estudiantes de nuevo ingreso no tienen una visióin estereotipada de la contabilidad y que esta visión no difiere sustancialmente de la de sus compañeros en carreras cercanas (administración de empresas y derecho). Aún más, los resultados no evidencian un empeoramiento de esta imagen debido al efecto de los primeros cursos en contabilidad, al menos para los alumnos en México.
\end{abstract}

PALABRAS CLAVE: Contabilidad, Estereotipos, México, Gap de expectativas.

\begin{abstract}
Both research and statements by stakeholders have notice the existence of the so called expectation performance gap, a divergence between the skills requirements to succeed in the accounting profession and the skills exhibited by graduates. Some authors point to a misinterpretation of required competencies by students, based on a stereotyped image of accounting that could lead to a possible self-selection bias. The main objective of this paper is study the perceptions on accounting in a sample of Mexican students enrolled in different degrees and courses. Our results, contrariwise to previous research, suggest that entry level students do not present a stereotyped perception on accounting and that those views do not differ substantially from other students at business of law degrees. Furthermore, our results do not support the negative effects of accounting education on students' perceptions, at least for Mexican students.
\end{abstract}

KEYWORDS: Stereotypes, expectation performance gap, Mexico, accounting.

Artículo. Recibido: 28-06-18 - Versión revisada: 14-09-18, Aceptado: 01-11-18

Licencia Creative Commons BY NC ND · 2018 · Asociación Española de Contabilidad y Administración de Empresas - AECA 


\section{INTRODUCTION}

Among other many authors, Allen (2004) highlighted the concern of the accounting profession about losing access to high-quality "accounting-type" students (p.235) that is evidenced in the so called Expectation performance gap: the mismatch between the competencies which the profession expects from entry level accountants and the perceptions on the level of such skills as exhibited by the graduating accounting students (Bui \& Porter, 2010; Webb \& Chaffer, 2016). Bui and Porter point to several possible causes, among them, the characteristic of students, including the perceptions about competencies required.

This misinterpretation of required competencies could lead to a possible self-selection bias, students that do not present an adequate profile enrol in accounting degrees or aim to entry into the profession because they feel there is no need for communication, teamwork or complex problem solving skills (Arquero, Fernández-Polvillo, Hassall, \& Joyce 2017), whereas those students presenting the required skills may opt for other careers (Saemann \& Crooker, 1999). In this line, Allen (2004) notes that "one explanation in the literature for the profession's failure to attract the desired student to the accounting major is that the perceived unappealing nature (image) of accounting deters non-accounting majors from choosing accounting as a major" (p.235) which leads to the impact of social stereotypes in such decisions. Nga and Wai Moon (2013) support this connection, stating that the negative media stereotype of accounting along with the inclination towards novelty and variety in job expectations may predispose negatively in the election of accounting as a career option (p.501).

The objective of this paper is to examine if there are strong stereotypical views in students enrolling in accounting degrees in Mexico comparing these views with (I) students in other competing degrees (business and law) and (II) accounting students in higher courses.

This paper adds to the very scarce literature on this topic outside the Anglo-Saxon literature, mainly focused in USA students.

\section{ACCOUNTING AS SEEN IN THE MEDIA}

It is clear that to some extent the image of a certain professions (in our case, accounting) as it is presented by the media has an influence on the preconceptions of students (Byrne \& Willis, 2005) and in their decisions about what career they would like to choose (Germanou, Hassall, \& Tournas, 2009). Cory (1992) indicates that the student's own perceptions of the qualities personified by members of the profession under consideration are one of the sources they rely upon on career-planning decisions, and that, according to Imada, Fletcher and Dalessio (1980) students preconceptions of the accountant's roles and tasks (stereotypes) differed substantially from the views of actual professionals or employers and can be regarded as "sterile". As a consequence, this negative image could discourage students from considering accounting as their future career (e.g. Wessels \& Steenkamp, 2009).

Davison and Warren (2009) highlight that "Accountants have suffered long-term stereotyping in popular culture, amplified through the media, and a stereotype which is overtly visual: the grey pin-stripe-suited male hunched over his abacus, "counting the beans'" (p. 848-849). This stereotype, closer to 19th century bookkeeping than to modern accounting is still shaping decisions, despite the attempts to change the image of accounting by firms (e.g. Baldvinsdottir, Burns, Nørreklit, \& Scapens, 2009; Jeacle, 2008). Thus Albretch and Sack (2000) concluded that the accounting stereotype is alive 
and well, presenting accountants as doing "boring, tedious and monotonous number crunching" (p. 28). Sometimes these stereotypes even affect the preconceptions of career advisers (Malthus \& Fowler, 2009) and consequently their suggestions.

Several research papers analysed the image of accountants in popular media. Beard (1994) focused in films and she remarked that:

Accountants are not traditionally regarded, at least by Hollywood, as part of the top management team. They are seen, instead, as undifferentiated cogs in the wheel of economic progress, cogs to be replaced without a moment's hesitation by other faceless accountants or, preferably, by advanced technology. (p.305)

As Arquero \& Fernandez-Polvillo (2018) highlight, the iconic image of Jack Lemmon in The Apartment, one of a myriad identical workers in wall-less office full of identical desks, is one of the best examples of this description (Picture 1).

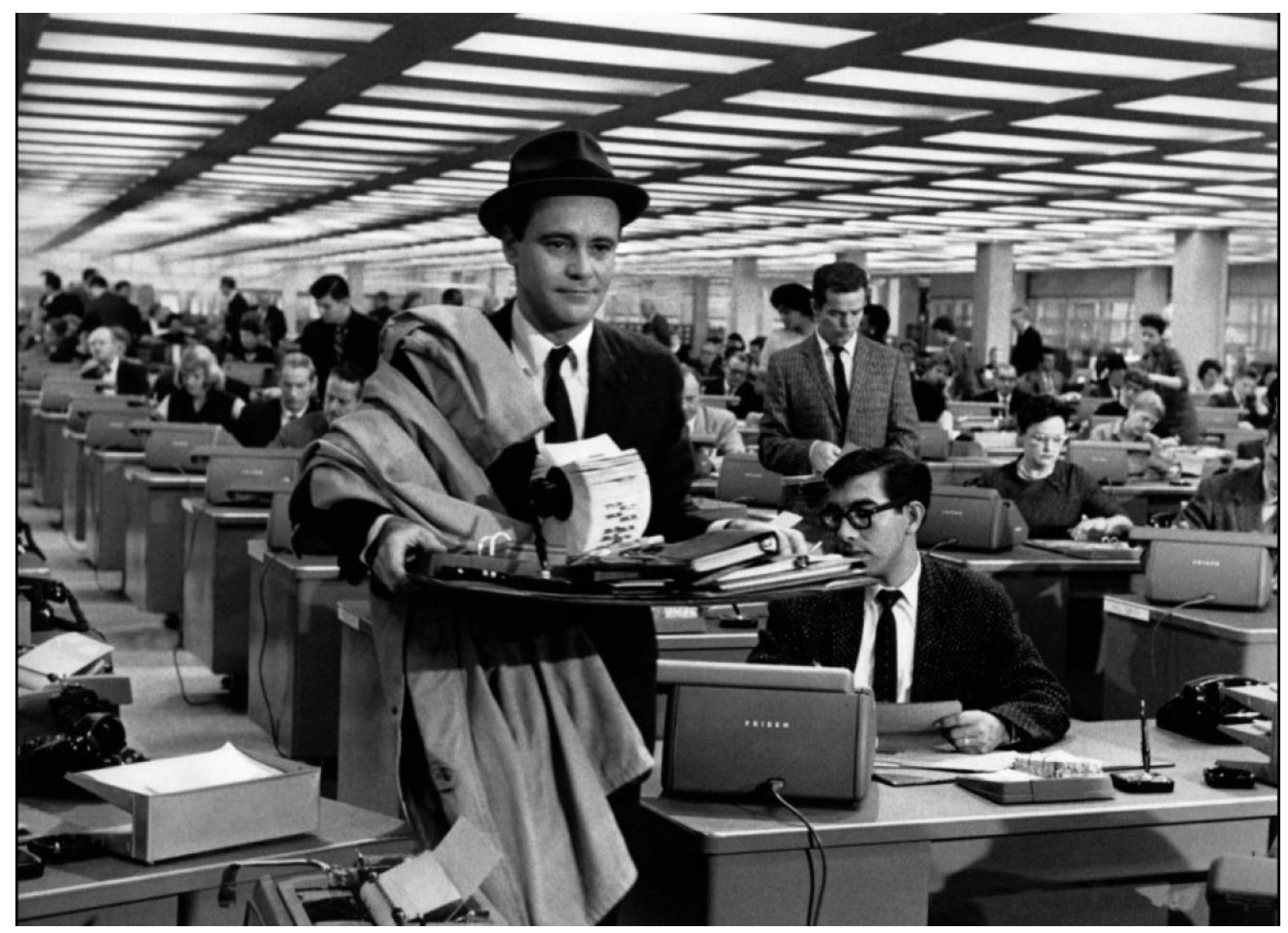

Picture 1: The Apartment. Dir. Billy Wilder, 1960, The Mirisch Company

Source: http://www.filmoteca.cat/web/sites/default/files/films/8891/imatges/apartamento_5.jpg

Dimnik and Felton (2006) stressed the enormous impact that movies have in reinforcing social stereotypes, given that they engage the audience much more intensely than other media. In their paper, Dimnik and Felton found that, although there was an improvement in the definition of the characters (increasingly more complex and showing a higher level of diversity), the stereotype persists and also noted that among the 37 characters that were specifically identified as having a professional accreditation (CP or CPA), only five appeared in films before 1981 (p.151).

Other research focused in the image of accounting and accountants in jokes (e.g. Bougen, 1994; Miley \& Read, 2012). Bougen (1994) highlighted that the typical stereotype, associated with bookkeeping had a negative image (boring, dull, etc.) but also a positive connotation of a trustworthy, cautious person you can rely on: "the 
portrayal of a risk averse, cautious person, who is likely to approach money management in a cautious, risk averse way" (Miley \& Read, 2012, p.713). To some extent, Bougen noted that recent scandals, and subsequent jokes and stories, added also a bad reputation. Accountants, then, are not only boring, but are also bad, incompetent and even corrupted.

Arquero and Fernandez-Polvillo (2018) pointed to the Monty Phiton's sketch The Vocational Guidance Counsellor as the paramount of the stereotype. The description of the accountant made in this sketch cannot be more devastating:

"Counsellor: Well, er, yes Mr Anchovy, but you see your report here says that you are an extremely dull person. You see, our experts describe you as an appallingly dull fellow, unimaginative, timid, lacking in initiative, spineless, easily dominated, no sense of humour, tedious company and irrepressibly drab and awful. And whereas in most professions these would be considerable drawbacks, in chartered accountancy they are a positive boon." (http://www.montypython.net/scripts/vocation.php)

The final speech to camera by John Cleese (who plays the role of the counsellor) just gives the coup de grace to the image of accounting that is labelled as "terrible debilitating social disease":

"Counsellor: (turning to camera) Well this is just one of the all too many cases on our books of chartered accountancy. The only way that we can fight this terrible debilitating social disease, is by informing the general public of its consequences, by showing young people that it's just not worth it. So, so please... give generously... to this address: The League for Fighting Chartered Accountancy, 55 (...)"

\section{STUDENTS AND IMAGE OF ACCOUNTING}

Wessels \& Steenkamp (2009) stated that literature demonstrates that negative stereotyped perceptions of the accountant appears to prevail. Several papers have studied that image of accounting and accountants as perceived by students, although as Albu, Albu, Gîrbinä and Sandu (2011) note the literature on this topic out of the Anglo-saxon context is really scarce.

The study of Saemann and Crooker (1999) examined the creativity and the perceptions of USA university students enrolled in the introductory accounting course. For that study, Saemann and Crooker developed a specific instrument consisting of 36 pair of opposing statements regarding the accounting profession. Their results indicate that initial perceptions support a traditional view of accounting as being structured, precise, and solitary. Further results highlighted that students enrolled in business schools tend to be less creative than other university students and, furthermore, after taking the accounting course those students declaring to be accounting majors presented lower levels of creativity in comparison with other business students (p.15).

Several other pieces of research used the questionnaire developed by Saemann and Crooker (1999) to gather students' perceptions of accounting (POA). Wessels and Steenkamp (2009) examined the perceptions of South African university students, concluding that "the traditional view of accountants still holds, namely that they are structured, precise and solitary individuals" (p.129). Sugahara, Hiramatsu \& Boland (2009) explored the link between several factors, including PoA, and the decision to become a CPA. Their results indicate that students perceive accounting as highly precise and average structured, but not an especially solitary work. Byrne and Willis (2005) explored Irish students' perceptions in a previous stage (secondary education). They concluded that the image of accounting held by those students is negative: "boring, definite, precise and compliance driven (p.377) and the main factors influencing these perceptions were the study of the subject in school, the factual media 
and their teachers. McDowall, Jackling \& Natoli (2012) also focused on secondary school students in Australia. Their results also confirm a view of accounting as boring and precise, but the attitudes of students enrolled in accounting courses appeared to be less stereotyped. In Spain, Arquero and Fernandez-Polvillo (2018) did not found significant differences in the PoA held by students in the accounting \& finance degree when comparing with fellow students enrolled in business administration degree. Spanish students viewed accounting as moderately precise and structured and not an especially solitary work, but clearly far from a profession where ambiguous and complex problems must be solved in creative ways and working in groups.

Nga and Wai Mun (2013), surveying business school students in Malaysia, reported a positive view of accountants as being highly professional (e.g. qualified for the job, skillful) and ethical. However the scores for good communicator or charismatic (associated with leadership in the study) presented the lower scores of all attributes. Marriott and Marriott (2003) noted English students enrolled in accounting courses with a reasonable positive PoA. However, those perceptions did not improve after studying accounting courses; contrariwise, were found to fell significantly at the end of the term. Very similar results were reported by Geiger and Ogilby (2000) for first year accounting students in USA universities.

The results by Malthus and Fowler (2009), in New Zealand, are to some extent divergent. Using a qualitative approach they confirmed that high school students and career advisers have a negative image of an accountant and a limited understanding of nowadays accounting job requirements; lack of knowledge that is also present in first year university students, for whom "the stereotype of an accountant as dull and boring is as strong as ever" (p. 41). However, they found that final year students had a more accurate understanding of what accounting demands and did not hold a negative image of the profession.

\section{RESEARCH QUESTIONS}

The main objective of the present study is to investigate the perceptions of accounting held by Mexican students, a population where the literature on this topic is almost inexistent. Therefore the main research question is formulated as follows:

RQ1: Do Mexican entry level students enrolled in accounting hold a stereotyped perception of accounting?

This question is complemented with the following:

RQ2: Do the PoA differ between accounting and other competing degrees entry level students?

As previous research suggested a change in the PoA when comparing first and final year students, or the same students after taking accounting courses, the third research question is:

RQ3: Are there significant differences in the POA when comparing entry level and final year accounting students' perceptions?

\section{METHODOLOGY}

\subsection{Instrument and data collection}

The instrument used is the Spanish version of the perceptions of the accounting profession inventory (PAPI) developed by Saemann and Crooker (2009). This instrument have been used in several pieces of research in accounting and finance in the original version (English) and was adapted to Spanish and previously used by Arquero and Fernandez-Polvillo (2018). The instrument consist of 36 pairs of opposing adjectives of short statements to be answered in a 5 point scale, were the answer shows the strength 
of the opinion in any of the directions, being 3 a neutral position. However, Saemann and Crooker only used 28 out of the 36 to build the scales.

These items allow obtaining four measures on PoA, namely:

$$
\begin{aligned}
& \text { structure/rule-orientation ( } 11 \text { items) } \\
& \text { thoroughness/precision ( } 10 \text { items) } \\
& \text { solitary-orientation in the field of accounting ( } 3 \text { items) } \\
& \text { interest of the area (4 items) }
\end{aligned}
$$

The questionnaires were distributed at the beginning of the course, in class time by a member of the research team. In order to minimize the of common method variance via research design we followed the procedure used by Arquero and Fernandez-Polvillo (2018), the member of the research team described the main objectives, but avoiding the suggestion of any relationship between variables. The confidentiality of data, that were collected anonymously were guaranteed, stressing that data were only to be treated for research purposes at an aggregated level. Finally, we asked for sincere responses stressing the inexistence of correct-incorrect answers or any kind of impact on the course assessment.

\subsection{Sample}

The sample consists of a total of 531 students enrolled in a public Mexican University. The composition of the sample by degree and course is presented in table 1. Three degrees were considered: accounting (n: 266), business administration (n: 114) and law (n: 151).

Table 1. Composition of the sample by degree and course

\begin{tabular}{llrrr}
\hline \multicolumn{4}{c}{ Course } & Total \\
& & first & upper & \\
\hline Degree & Accounting & 100 & 166 & 266 \\
& Business & 50 & 64 & 114 \\
& Law & 85 & 66 & 151 \\
Total & & 235 & 296 & 531 \\
\hline
\end{tabular}

About $65 \%$ of the students in accounting and business are female, percentage that is slightly reduced in law (58\% female vs $42 \%$ male) with an average age of 21 years old for all degrees.

\section{RESULTS}

Table 2 presents the scores in each scale obtained for first year students in the three degrees involved. Although some statistically significant differences arise, those dissimilarities are not substantial. First year students present a mainly neutral opinion of accounting in terms of precision or solitary work. They found the area as moderately interesting (mean score of 3.5 out of 5) and structured (mean: 3.35). It is to be noted that law students found accounting to be more structured than any of their fellow students (mean: 3.65) whereas business presented the lowest score (mean: 3.03).

Therefore, considering the results, the answer to RQ1 is that accounting students at entry level do present a stereotyped perception of accounting. Regarding RQ2, no substantial differences appeared, although the mean values presented statistically significant differences in three of the four scales: precision (2.55 law vs 2.91 business students), solitary work (3.08 accounting vs 2.91 law students) and structure. (3.03 business vs 3.65 law students). 
Carmen Fernández_Polvillo, Gracia.P. Michel Vázquez

Accounting and stereotypes. A comparative analysis of Mexican students' perceptions

Table 2. Main scores by degree (first year students)

\begin{tabular}{|c|c|c|c|c|c|}
\hline & & & Mean & $S D$ & Anova sig. \\
\hline \multirow{4}{*}{ SC_interest } & Accounting & 100 & 3,44 & 0,63 & \multirow[t]{4}{*}{ n.s. } \\
\hline & Business & 50 & 3,57 & 0,49 & \\
\hline & Law & 85 & 3,57 & 0,64 & \\
\hline & Total & 235 & 3,51 & 0,61 & \\
\hline \multirow[t]{4}{*}{ SC_precision } & Accounting & 100 & 2,88 & 0,55 & \multirow[t]{4}{*}{.000} \\
\hline & Business & 50 & 2,91 & 0,44 & \\
\hline & Law & 85 & 2,55 & 0,67 & \\
\hline & Total & 235 & 2,77 & 0,60 & \\
\hline \multirow[t]{4}{*}{ SC_solitary } & Accounting & 100 & 3,08 & 0,59 & \multirow[t]{4}{*}{.027} \\
\hline & Business & 50 & 2,72 & 0,82 & \\
\hline & Law & 85 & 2,91 & 0,95 & \\
\hline & Total & 235 & 2,94 & 0,80 & \\
\hline \multirow[t]{4}{*}{ SC_structure } & Accounting & 100 & 3,26 & 0,60 & \multirow[t]{4}{*}{.000} \\
\hline & Business & 50 & 3,03 & 0,60 & \\
\hline & Law & 85 & 3,65 & 0,62 & \\
\hline & Total & 235 & 3,35 & 0,65 & \\
\hline
\end{tabular}

In order to examine potential differences in depth, in table 3 , the scores by degree of some of the most relevant items are presented. At item level relevant differences appear.

Table 3. Detailed scores by degree (first year students)

\begin{tabular}{l|rrrrr}
\hline items & Account & Business & Law & Total & \multicolumn{2}{c}{$\begin{array}{c}\text { Anova } \\
\text { sig }\end{array}$} \\
\hline Boring-Interesting & 3,85 & 4,18 & 4,42 & 4,13 & 0,000 \\
Creative Solutions-Cut\&Dry & 2,86 & 2,54 & 3,35 & 2,97 & 0,000 \\
Repetition-Variety & 3,62 & 3,78 & 3,80 & 3,72 & n.s. \\
New Ideas-Established Rules & 3,28 & 3,04 & 3,91 & 3,46 & 0,000 \\
Flexible-Structured & 3,41 & 3,22 & 4,06 & 3,60 & 0,000 \\
Solitary-Interaction With Others & 3,60 & 3,98 & 4,02 & 3,83 & 0,019 \\
Conformity-Originality & 3,67 & 3,78 & 3,94 & 3,79 & n.s. \\
Standard Procedures-New Solutions & 3,47 & 3,48 & 3,44 & 3,46 & n.s. \\
Ambiguity-Certainty & 3,73 & 3,84 & 4,19 & 3,92 & 0,008 \\
Alternative Views-Uniform Standards & 3,28 & 2,94 & 3,58 & 3,31 & 0,006 \\
Record Keeping-Decision Making & 3,28 & 3,58 & 3,82 & 3,54 & 0,011 \\
Mathematical-Verbal & 2,81 & 3,28 & 4,42 & 3,49 & 0,000 \\
\hline
\end{tabular}

It is to be noted that law students have the most positive perception of accounting in terms of interesting (mean: 4.42), interactive (mean: 4.02), original (mean: 3.94), verbal (mean: 4.42) and decision making oriented (mean: 3.82). However are also law students who have the most stereotyped image of accounting in terms of less creative (vs cut\&dry; mean: 2.86), oriented to established rules (mean: 3.91), uniform standards (mean: 3.58), structured (mean: 4.06) and certain (mean: 4.19). Accounting students present the lowest score, although close to 4, for interesting (mean: 3.85 ) and perceive accounting to be more linked to mathematics and numbers that verbal (mean: 2.81). Therefore, at items level the answer to $R Q 2$ is more complex, because the perceptions of the area differ in specific aspects; certainly not in the sense of holding opposing views, but with noticeable divergence in some particular items. 
Some authors pointed to a consolidation or even increasing stereotyped image of accounting after being exposed to accounting courses. In order to analyse this possible evolution of the perceptions, the scores of first year students were compared with the PoA held by higher courses accounting students (table 4).

The results indicate that there is only a significant difference when comparing accounting students at different courses. Students that went through accounting courses perceive accounting as more interesting than entry level students. Therefore, responding to RQ3, no major effects in the perceptions of accounting are found; and if any it is positive.

Table 4. Main scores by course (accounting students)

\begin{tabular}{l|lrrrr}
\hline & & & Mean & SD & Anova sig \\
\hline SC_interest & 1st course & 100 & 3,44 & 0,63 & 0,000 \\
& Higher courses & 166 & 3,77 & 0,69 & \\
& Total & 266 & 3,64 & 0,68 & \\
SC_precision & 1 st course & 100 & 2,88 & 0,55 & 0,076 \\
& Higher courses & 166 & 3,01 & 0,60 & \\
& Total & 266 & 2,96 & 0,59 & \\
SC_solitary & 1st course & 100 & 3,08 & 0,59 & n.s \\
& Higher courses & 166 & 2,95 & 0,72 & \\
& Total & 266 & 3,00 & 0,67 & \\
SC_structure & 1 lst course & 100 & 3,26 & 0,60 & n.s \\
& Higher courses & 166 & 3,23 & 0,64 & \\
& Total & 266 & 3,24 & 0,62 & \\
\hline
\end{tabular}

\section{DISCUSSION}

The main objective of the present study was to investigate the perceptions of accounting (POA) held by Mexican students, a population where the literature on this topic is almost inexistent. These analysis is threefold: first studying the PoA held by entry level students, second, comparing the views of accounting students with those held by students enrolled at competing degrees (law and business) and third, testing if any significant changes occur due to the exposure to accounting courses.

Our results, utilizing a widely used instrument (Saemman \& Crooker, 1999) indicate that entry level students do not have a stereotyped image of accounting, in contrast with the results obtained by previous research (e.g. Saemann \& Crooker, 1999 or Wessels \& Steenkamp, 2009). When comparing the views of students enrolled in different degrees, those views, at least at scale level do not differ substantially, in line with the results reported by Arquero and Fernandez-Polvillo (2018) for Spanish students of accounting and business using the same instrument.

Therefore, our results do not support a self-selection bias due to misconception of accounting professional requirements that could result in relevant and systematically biased differences in the PoA held by different students.

Finally, Marriott and Marriott (2003) and Geiger and Ogilby (2000), among others, pointed to a negative influence of the first courses of accounting in the image of the profession held by students. Our results do not support this assertion for the Mexican case. The perceptions of entry level and upper courses students do not differ and the only noticeable difference is positive: upper courses students perceive accounting as more interesting than entry level students. 
Limitations and further research

The sample is composed by students at one university. In order to obtain more generalizable results a wider sample could be needed. The results and conclusions about the influence of accounting education in the PoA is based upon the comparison at the same time of students enrolled in different courses, not in the data from the same students as they progressed over time. A longitudinal study could present a more accurate insight on the evolution of perceptions.

Finally, in line with the limitations raised by Arquero and Fernandez-Polvillo (2018), we consider that semantic differential scales, in many cases, are not easily understood by students, who sometimes do not perceive the two statements as clearly opposed or do not share the same meaning.

\section{Acknowledgements}

The data used in this paper were obtained from a wider Project funded with a PROMEP grant (Programa de Mejoramiento del Profesorado, Dirección General Educación Superior Universitaria, gobierno de México).

\section{REFERENCES}

Albrecht, W. S. and Sack, R. J. (2000). Accounting Education: Charting the Course through a Perilous Future, Accounting Education Series Vol. 16 (Sarasota, FL: American Accounting Association).

Albu, N., Albu, C.N., Gîrbinä, M. M., \& Sandu, M. I. (2011). A framework for the analysis of the stereotypes in Accounting. International Scholarly and Scientific Research and Innovation, 5(5), pp. 732-736.

Allen, C. L. (2004). Business students' perception of the image of accounting. Managerial Auditing Journal, 19(2), 235-258.

Arquero, J. L., \& Fernández-Polvillo, C. (2018). Estereotipos contables. Motivaciones y percepciones sobre la contabilidad de los estudiantes universitarios de Administración de Empresas y Finanzas y Contabilidad. Revista de Contabilidad. In press.

Arquero, J. L., Fernández-Polvillo, C., Hassall, T., \& Joyce, J. (2017). Relationships between communication apprehension, ambiguity tolerance and learning styles in accounting students. Revista de Contabilidad. 20 (1) 13-24.

Baldvinsdottir, G., Burns, J., Nørreklit, H., \& Scapens, R. W. (2009). The image of accountants: from bean counters to extreme accountants. Accounting, Auditing \& Accountability Journal, $22(6), 858-882$.

Beard, V. (1994), Popular culture and professional identity: accountants in the movies, Accounting, Organizations and Society, 19 (3), 303-18.

Bougen, P.D. (1994), Joking apart: the serious side to the accountant stereotype, Accounting, Organizations and Society, Vol. 19 No. 3, pp. 319-35.

Bui, B., \& Porter, B. (2010). The expectation-performance gap in accounting education: an exploratory study. Accounting Education: an international journal, 19(1-2), 23-50.

Byrne, M., \& Willis, P. (2005). Irish secondary students' perceptions of the work of an accountant and the accounting profession. Accounting Education: an international journal, 14 (4), 367-381.

Cory, S.N. (1992), Quality and quantity of accounting students and the stereotypical accountant: is there a relationship?, Journal of Accounting Education, 10 (1), 124. 
Davison, J., \& Warren, S. (2009). Imag[in]ing accounting and accountability. Accounting, Auditing \& Accountability Journal, $22(6), 845-857$.

Dimnik, T., \& Felton, S. (2006). Accountant stereotypes in movies distributed in North America in the twentieth century. Accounting, Organizations and Society, 31 (2), 129-155.

Geiger, M. and Ogilby, S. (2000) The first course in accounting: students' perceptions and their effect on the decision to major in accounting, Journal of Accounting Education, 18(2), pp. 63-78.

Germanou, E., Hassall, T., \& Tournas, Y. (2009). Students' perceptions of accounting profession: work value approach. Asian Review of Accounting, 17(2), 136-148.

Imada, A. S., Fletcher, C., \& Dalessio, A. (1980). Individual correlates of an occupational stereotype: A reexamination of the stereotype of accountants. Journal of Applied Psychology, 65(4), 436-439.

Jeacle, I. (2008). Beyond the boring grey: The construction of the colourful accountant. Critical Perspectives on Accounting, 19(8), 1296-1320.

Malthus, S., \& Fowler, C. (2009). Perceptions of accounting: a qualitative New Zealand study. Pacific Accounting Review, 21 (1), 26-47.

Marriott, P. R. U., \& Marriott, N. (2003). Are we turning them on? A longitudinal study of undergraduate accounting students' attitudes towards accounting as a profession. Accounting education, $12(2), 113-133$.

McDowall, T., Jackling, B., \& Natoli, R. (2012). Are we there yet? Changing perceptions of accounting as a career preference. The International Journal of Learning, 18(4), 335-352.

Miley, F., \& Read, A. (2012). Jokes in popular culture: the characterisation of the accountant. Accounting, Auditing \& Accountability Journal, 25(4), 703-718.

Nga, J. K., \& Wai Mun, S. (2013). The perception of undergraduate students towards accountants and the role of accountants in driving organizational change: A case study of a Malaysian business school. Education+ Training, 55(6), 500-519.

Saemann, G. P., \& Crooker, K. J. (1999). Student perceptions of the profession and its effect on decisions to major in accounting. Journal of Accounting Education, $17(1), 1-22$.

Sugahara, S., Hiramatsu, K., \& Boland, G. (2009). The factors influencing accounting school students' career intention to become a Certified Public Accountant in Japan. Asian Review of Accounting, 17(1), 5-22.

Webb, J., \& Chaffer, C. (2016). The expectation performance gap in accounting education: A review of generic skills development in UK accounting degrees. Accounting Education, 25(4), 349-367.

Wells, P.; Gerbic, P.; Kranenburg, I. \& Bygrave, J. (2009). Professional Skills and Capabilities of Accounting Graduates: The New Zealand Expectation Gap? Accounting Education: An International Journal, 18 (4-5), 403-420

Wessels, P. L., \& Steenkamp, L. P. (2009). An investigation into students' perceptions of accountants. Meditari Accountancy Research, 17(1), 117-132. 